ROCZNIKI TEOLOGICZNE

Tom LXVII, zeszyt $12-2020$

DOI: https://dx.doi.org/10.18290/rt206712-3

IGNACY KOSMANA OFMConv

\title{
KATECHETA XXI WIEKU - NAUCZYCIEL RELIGII CZY EWANGELIZATOR?
}

\author{
$21^{\text {st }}$ CENTURY CATECHIST - A RELIGION TEACHER, \\ OR AN EVANGELIZER?
}

\begin{abstract}
A b stract. The author, basing on church documents and theological elaborations, presents challenges for the $21^{\text {st }}$-century catechist in the context of a changing world and its new (second) evangelization. Modern-day Christians - people who have received the sacrament of Baptism - have departed far from Christ. Hence the need for re-evangelization and recatechization of nominally believing societies. The purpose of evangelizing catechesis understood in this way is to bring this world back to Christ, to establish relationships with him and to deepen mutual relations: God-human. The material analyzes the shortcomings and errors of the modern catechist. Pastoral suggestions and indications were also given and perspectives for new evangelizers were shown. The church faces a great mission. It is not only the expansion of the Lord's disciples, but also the recovery of the lost who have withdrawn and no longer walk with him (compare John 6:66). The evangelizer, in reality that is constantly secularizing and secularizing, can contrast God's living Word and his own living testimony. Currently, he has many tools at his disposal to reach the recipients - former disciples who were discouraged by the Church because of its difficult speech (John 6:60), or scandals and abuses of the clergy. The church is determined to constantly reaffirm the irreplaceable role of teachers in its mission. It is also a task for catechists themselves who, identifying with the Teacher of Nazareth, should be aware of the mission entrusted to them by the Church.
\end{abstract}

Key words: evangelization; catechization; catechist; teacher; evangelizer.

Dr hab. Ignacy Kosmana OFMConv - wykładowca homiletyki w Wyższym Seminarium Ojców Franciszkanów w Łodzi-Łagiewnikach oraz Wyższym Seminarium Duchownym Towarzystwa Chrystusowego dla Polonii Zagranicznej w Poznaniu; adres do korespondencji: Klasztor Zakonu Braci Mniejszych Konwentualnych w Niepokalanowie, ul. M. Kolbego 5, 96-515 Teresin; e-mail: igorkos4@wp.pl. ORCID: 0000-0003-2183-498X. 


\section{WSTĘP}

Życie Kościoła oraz wszystkie formy jego apostolskiej działalności służą głoszeniu orędzia Bożego. Dokonuje się to w sposób szczególny przez posługę słowa, czyli żywe przepowiadanie, w którym wyróżnia się trzy podstawowe formy. Po pierwsze, jest to ewangelizacja, czyli przepowiadanie wiary; dzięki ewangelizacji słuchacz styka się z orędziem zbawczym Kościoła; celem ewangelizacji jest nawrócenie, które jest początkiem wiary. Po drugie, jest to katechizacja - jej celem jest prowadzenie wspólnoty i poszczególnych wiernych drogą wiodącą ku dojrzałości wiary (dojrzewanie w wierze jest procesem trwającym do końca ludzkiego życia). Po trzecie wreszcie, jest to homilia, która jest najwyższą formą przepowiadania wiary, bo jest związana z liturgią, obejmującą całokształt życia człowieka; celem homilii jest podtrzymywanie życia wiary ${ }^{1}$.

Tematem niniejszego artykułu jest rola katechety w XXI wieku. Jeszcze do niedawna katecheta pozostawał nauczycielem religii, $w$ obecnych jednak czasach coraz częściej odgrywa rolę ewangelizatora, a ściślej - reewangelizatora w ramach „nowej ewangelizacji”, obejmującej swoimi działaniami wiernych „nominalnych”, ludzi ochrzczonych, ale pozostających na peryferiach wiary i Kościoła ${ }^{2}$.

\section{NOWA EWANGELIZACJA A KATECHIZACJA}

Zagadnienie nowej (drugiej) ewangelizacji i katechizacji jest tematem szczególnie ważnym w obecnych czasach - przemian cywilizacyjnych, w tym pogłębiającego się zeświecczenia społeczeństw nominalnie chrześcijańskich. Problemom katechizacji i nowej ewangelizacji poświęca coraz więcej uwagi Kościół w osobach swoich pasterzy: papieży (Jan Paweł II, Paweł $\mathrm{VI}^{3}$, Franciszek) ${ }^{4}$ i biskupów ${ }^{5}$ oraz teologów - osób duchownych i świeckich ${ }^{6}$.

\footnotetext{
${ }^{1}$ Por. H. SŁawińSKi, Rola homilii w liturgii Kościoła, „Studia Włocławskie” 4 (2001), s. 290; R. Murawski, Katecheza, w: Katolicyzm A-Z, red. Z. Pawlak, Wydawnictwo: Księgarnia Św. Wojciecha, Poznań 1982, s. 198-199.

${ }^{2}$ Por. Jan PAwEe II, Encyklika Redemptoris Mater, nr 33, https://opoka.org.pl/biblioteka/ W/WP/ jan_pawel_ii/encykliki/r_mater_1.html (dostęp: 01.04.2020) [dalej: RM].

${ }^{3}$ PAwę VI, Adhortacja Apostolska o ewangelizacji w świecie współczesnym Evangelii nuntiandi, Rzym 1975; tłum. polskie aprobowane przez KEP: „Miesięcznik Kościelny Archidiecezji Poznańskiej” 1975, nr 7-8 [dalej: EN].
} 
Katecheta XXI wieku - to brzmi dumnie, ale katecheci istnieli od początku historii Kościoła i zawsze byli dumą wspólnot chrześcijańskich. Należy zaznaczyć, że inną pracę wykonuje ewangelizator, a inną katecheta. Ewangelizator jest „siewcą ziarna”, natomiast katecheta - ogrodnikiem doglądającym drzewa figowego (Łk 13,6-9a). Ziarno ewangelizatora pada na różną glebę, bywa że nie przynosi plonu, trzeba starań katechety, żeby przyniosło zysk - stokrotny, sześćdziesięciokrotny lub przynajmniej trzydziestokrotny (Mt 13,1-9).

Celem katechezy ${ }^{7}$ jest spotkanie z Jezusem, zjednoczenie z Nim, głęboka z Nim zażyłość. Katecheza ma zatem charakter chrystocentryczny. Z chrystocentryzmu wynika jej teocentryzm. Z kolei związek Chrystusa z Kościołem i z ludźmi wierzącymi implikuje eklezjocentryzm i chrześcijański personalizm katechezy ${ }^{8}$.

Celem ewangelizacji jest przekazywanie „wartości Królestwa”, takich jak: pokój, sprawiedliwość, wolność, braterstwo. Nie wolno jednak zapominać, że te wartości mają swoje źródło w Chrystusie, stąd też nie można przemilczać Osoby Jezusa Chrystusa - podmiotu ewangelizacji. Przecież nie kto inny, jak „sam Jezus, Ewangelia Boga, był pierwszym i największym głosicielem Ewangelii" ". Ewangelizacja niesie z sobą określoną doktrynę oraz program działania, których nie można przedstawiać dowolnie, po swojemu opracowywać, komentować według własnego uznania. Ewangelizacja ma oblicze Jezusa z Nazaretu, będącego obrazem (ikoną) Boga niewidzialnego; nie może to być oblicze ewangelizatora, katechety czy homilisty ${ }^{10}$.

\footnotetext{
${ }^{4}$ JAN PAwEŁ II, Adhortacja Apostolska o katechizacji w naszych czasach Catechesi tradendae, Rzym 1979 [dalej: CT]; Franciszek, Adhortacja Apostolska Evangelii gaudium, Rzym 2013 [dalej: EG].

${ }^{5}$ Na przykład: P.J. CoRdes, Nowa ewangelizacja w rozumieniu Jana Pawła II, „L'Osservatore Romano" 4 (2012), s. 57-60; G. RYś, Moc wiary, Wydawnictwo WAM, Kraków 2017.

${ }^{6} \mathrm{Na}$ szczególną uwagę zasługuje w tym względzie dorobek ks. Romana Murawskiego SDB, obejmujący dziesiątki publikacji na temat katechizacji - zob. Wykaz publikacji Księdza Profesora Romana Murawskiego SDB, „Seminare” 2001, nr 17, s. 23-31. Zob. też: A. OsŁawska, Kaznodziejstwo chrześcijańskie na horyzoncie XXI wieku, w: W nurcie odnowy przepowiadania homilijnego, red. nauk. I. Kosmana, L. Pintal, Wydawnictwo Ojców Franciszkanów, Niepokalanów 2011, s. 283-293.

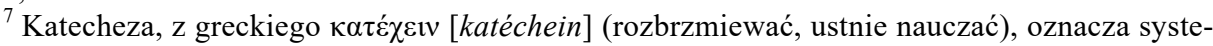
matyczne pouczenie w sprawach wiary oraz odpowiednie wprowadzenie w całokształt życia chrześcijańskiego. Por. R. Murawski, Katecheza, s. 198.

${ }^{8}$ Por. Konferencja EpisKopatu POLSKi, Dyrektorium katechetyczne Kościola katolickiego w Polsce, Wydawnictwo WAM, Kraków 2002, nr 21 [dalej: DK].

${ }^{9}$ PAwEt VI, Adhortacja Apostolska Evangelii nuntiandi, nr 7, https://opoka.org.pl/ biblioteka/ W/WP/pawel_vi/adhortacje/evangelii_nuntiandi.html [dostęp: 02.04.2020].

${ }^{10}$ Por. RM, nr 17-18.
} 
Z kolei homilia jest „po prostu poufną rozmową kaznodziei z wiernymi, w ramach czynności liturgicznej; rozmową o tekście biblijnym lub liturgicznym, który zaproponowała liturgia danego dnia. Nie jest to zatem ani mowa artystyczna, ani uroczysta... ${ }^{11}$. Jeśli chodzi o treść, homilia jest głoszeniem Chrystusa i Jego zbawczego dzieła, które realizuje się w danym miejscu i czasie; jest zaproszeniem do włączenia się słuchaczy do nieustannego nawracania się i praktykowania życia sakramentalnego. Celem homilii jest pouczenie wiernych w wierze i zachęta do moralności, którą już praktykują $^{12}$. Biorąc pod uwagę fakt, że katechetami są również osoby świeckie, to ten element posługiwania zostanie pominięty w niniejszym opracowaniu.

Kim zatem winien być katecheta w XXI wieku - ewangelizatorem (reewangelizatorem) czy nauczycielem religii? Pytanie wcale nie jest retoryczne, a odpowiedź - jednoznaczna.

\section{KATECHECI AWANGARDĄ KOŚCIOŁA}

Katecheta nie jest osobą wyrwaną z kontekstu Ewangelii. Stanowi przednią straż Kościoła, jego awangardę. Postawa ewangelizacyjna jest naturalnym odruchem chrześcijaństwa i konkretnego chrześcijanina. Wypływa ona z chrztu świętego, który wszczepiając człowieka do wspólnoty apostolskiej Kościoła, uzdalnia każdego nowo ochrzczonego do aktywności ewangelizacyjnej $^{13}$. Owocem chrztu są natura i godność nowo narodzonego chrześcijanina ( $\mathrm{J} 3,5)$; są one jednocześnie podstawą i źródłem chrześcijańskiego powołania. Dzięki otrzymanemu znamieniu ochrzczeni przeznaczeni są nie tylko do praktykowania kultu w ramach wspólnoty chrześcijańskiej, ale jako odrodzeni w wodzie i Duchu są zobowiązani wyznawać swoją wiarę publicznie przez żywy przykład zaszczepiać ją w sercach bliźnich ${ }^{14}$. Apostolski wymiar chrztu jest widoczny od samego początku istnienia Kościoła (Dz 2, 38). Adam Sikora przekonuje: „Uwierzyć, nawrócić się, przyjąć chrzest, doświadczyć miłosierdzia, otrzymać dar Ducha Świętego - to składowe ludzkiego doświadczenia w spotkaniu z rodzącym się Kościołem. Te same

\footnotetext{
${ }^{11}$ W. GŁowA, Liturgia miejscem i źródtem przepowiadania, Wydawnictwo Archidiecezji Przemyskiej, Przemyśl 1999, s. 102.

${ }^{12}$ Por. H. SŁAwiŃSKi, Rola homilii w liturgii Kościoła, s. 293.

${ }^{13}$ Por. EG, nr 119-120.

${ }^{14}$ Por. SobóR WATYKŃSKi II, Konstytucja dogmatyczna o Kościele Lumen gentium, w: Sobór Watykński II, Konstytucje, Dekrety, Deklaracje, tekst polski, nowe thumaczenie, Pallottinum, Poznań 2012, nr 11 [dalej: KK].
} 
składowe trzeba widzieć w doświadczeniu każdego ochrzczonego - niezależnie od wszelkich czasoprzestrzennym uwarunkowań"15. Chrzest jest u początku apostolskiego, ewangelizacyjnego oddziaływania zarówno całej wspólnoty na poszczególnego członka, jak i poszczególnych chrześcijan na wspólnotę $\mathrm{w}$ ramach apostolstwa wewnętrznego, czyli - szczególnie w obecnych czasach - działań reewangelizacyjnych.

W takiej perspektywie katecheci stanowią „żywe kamienie” i „duchową świątynię”, w której winni sprawować „święte kapłaństwo” (por. 1 P 2,5). Święty Piotr podkreśla z mocą: „Wy jesteście wybranym plemieniem, królewskim kapłaństwem [...], abyście ogłaszali dzieła potęgi Tego, który was wezwał..." (1 P 2,9). Przynależność do Kościoła oraz sprawowanie w nim funkcji nauczyciela (katechety) oznacza przyjęcie na siebie misji ewangelizacyjnej. Katecheta nie tylko poprzez chrzest, ale również przez swój szczególny charyzmat otrzymany od Ducha Świętego uczestniczy w potrójnym urzędzie Chrystusa: kapłańskim, prorockim i królewskim.

Kapłaństwo ma przede wszystkim wymiar ofiarniczy: „Ze względu na swoje kapłaństwo Jezus samego siebie wydał na krzyżu i nieustannie ofiarowuje się w Eucharystii na chwalę Ojca, dla naszego zbawienia" ${ }^{\prime 6}$. Katecheta, uczestnicząc w kapłaństwie Chrystusa, łączy się z Nim w tej ofierze, ofiarowując siebie samego i wszystkie swoje uczynki ${ }^{17}$. Katechizacja jest zatem formą ewangelizacji - uczestnictwem w Boskim posłannictwie Jezusa Chrystusa. Wymiar prorocki odnosi się przede wszystkim do świadectwa życia. Życiowa postawa katechety nie może stać w opozycji czy sprzeczności z głoszonym przezeń Słowem. Z kolei natura „królewskości” katechety winna wyrażać się $\mathrm{w}$ dwu aspektach jego życia: w nieustannej walce z samym sobą, czyli z własnymi grzechami i ułomnościami, oraz w królowaniu nad braćmi, które ukazał Chrystus Apostołom w Wieczerniku, polegającym na służeniu bliźnim (J 13,12-17) ${ }^{18}$.

Katechizacja jest misją. Misyjność zakłada wyjście do słuchaczy. Niestety we współczesnych realiach to słuchacze przychodzą do klasy czy salki katechetycznej. Katecheta jest więc bardziej nauczycielem religii niż ewangelizatorem. Tymczasem „salką katechetyczną” Jezusa były rozległe przestrzenie Palestyny, Galilei, Judei, Dekapolu, Sydonu, Tyru, Zajordania. Były ludzkie serca.

\footnotetext{
${ }^{15}$ A. SiKORA, Chrzest jako źródto apostolstwa świeckich, „Teologia i Moralność” 10 (2015), nr 1, s. 83.

${ }^{16}$ JAN Pawet II, Posynodalna Adhortacja Apostolska Christifideles Laici, nr 14, https:// opoka.org.pl/biblioteka/W/WP/jan_pawel_ii/adhortacje/christifideles.html [dostęp: 01.04.2020].

${ }^{17}$ Por. tamże.

${ }^{18}$ Por. A. SiKora, Chrzest jako źródto apostolstwa świeckich, s. 81-88.
} 


\section{POSTAWY I ZASADY EWANGELIZACYJNE KATECHETY}

Jaka zatem powinna być postawa katechety-ewangelizatora w XXI wieku? Wyczekująca - w salce katechetycznej czy szkolnej sali lekcyjnej? Czy też ekspansywna, aktywna, dynamiczna, wychodząca poza mury i kraty - na ulice miast?

Odpowiedź znajdujemy w Ewangelii według św. Łukasza w ósmym rozdziale $(Ł k$ 8,13), gdzie Ewangelista przedstawia opis konkretnej postawy ewangelizacyjnej Jezusa. Jezus nie czekał na uczniów. Sami przychodzili do Niego. Jezus nie czekał też na swoich słuchaczy. Nie było przecież takiego miejsca, w którym Syn Człowieczy „głowę mógł oprzeć” (Łk 9,58); które można by nazwać Jego „salką katechetyczną” czy Jego mieszkaniem. Jaka była zatem katechetyczna, ewangelizacyjna postawa Jezusa?

Najpierw polegała ona na wyjściu do ludzi: „Jezus wędrował przez miasta i wsie". Następnie - na głoszeniu Dobrej Nowiny o Królestwie Bożym, na nauczaniu. Zwraca uwagę fakt, że Jezus nie był sam. Towarzyszyli mu Apostołowie oraz kilka kobiet, „które zostały uwolnione od złych duchów i chorób” - Maria, Joanna, Zuzanna, ,i wiele innych, które im usługiwały”. Ewangelizacja $\mathrm{z}$ natury jest wspólnotowa, eklezjalna, kościelna. Nie ma ewangelizacji w pojedynkę. Ewangelizacja nie jest prywatną, indywidualną sprawą katechety. Nawet Jezus potrzebował Kościoła, gdy wędrował przez miasta i wsie ${ }^{19}$.

Przedstawiony przez św. Łukasza opis nie jest zwykłą relacją z wydarzenia. „To - jak pisze abp Grzegorz Ryś - Objawienie”20. W przytoczonym tekście co prawda nie pada ani jedno słowo Jezusa, tym niemniej Objawienie Boże dokonuje się nie tylko przez słowo, lecz również przez czyny. W greckim oryginale wspomniany opis zaczyna się od greckiego

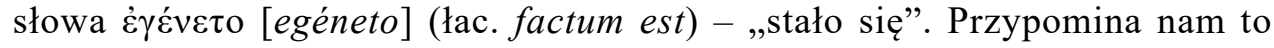
sformułowania użyte w pierwszym rozdziale Księgi Rodzaju. Tak stały się: niebo i ziemia, dzień i noc, ląd i morze, słońce i gwiazdy etc.

„I stało się, że Jezus wędrował przez miasta i wsie”. Tak stała się Ewangelizacja. Pierwsza. Jezusowa. Wzorcowa, bo „wyznaczająca zasady każdej następnej (po dzisiejszą) i postawy obowiązujące każdego, kto chce w niej uczestniczyć" ${ }^{21}$.

\footnotetext{
${ }^{19}$ Por. G. RYś, Moc wiary, s. 148.

${ }^{20}$ Tamże, s. 147

${ }^{21}$ Tamże.
} 
Taką też zasadę działania obrał św. Franciszek z Asyżu. Swego czasu udał się on $\mathrm{w}$ towarzystwie jednego $\mathrm{z}$ braci do miasta $\mathrm{w}$ celu wygłoszenia kazania. Chodzili obaj przez cały dzień w ubogim odzieniu, wystawiając się na kpiny i szyderstwa przechodniów. Pod koniec dnia ów brat zapytał Franciszka, kiedy zaczną głosić kazanie. Święty odrzekł mu na to, że już je wygłosili. „Jeśli twoje ubranie jest przesiąknięte zapachem mchu, nie ma potrzeby, byś mówił o tym wszystkim. Zapach będzie mówił sam za siebie. Najlepszym kazaniem jesteś ty sam"22.

Taka postawa, bez słów, czyli wyjście do ludzi i pokazanie im wartości chrześcijańskich, stanowi jedną z zasad ewangelizacyjnych, a co za tym idzie - katechetycznych. Jezus - największy Nauczyciel (Katecheta) - był stale $\mathrm{w}$ drodze. Nie przebywał w jednym, określonym miejscu. Nie miał stałego „zameldowania”. Wędrował. Wychodził do ludzi. Czynił tak nie dlatego, że lubił chodzić albo przebywać w towarzystwie innych. Czynił tak, bo taka była wola Jego Ojca, żeby „także innym miastom [...] głosić Dobrą Nowinę o królestwie Bożym" (por. Łk 4,43). Po to został posłany.

Postawa ewangelizacyjna katechety nie obejmuje tak rozległych przestrzeni, zwykle ogranicza się do parafii. Nie może jednak ograniczać się do przysłowiowej zakrystii. Katecheta-ewangelizator (reewangelizator) jest zdeterminowany do permanentnego wychodzenia i głoszenia królestwa Bożego z Kościołem i w imieniu Kościoła. Ta obecność Kościoła przy nim ma wiele wymiarów. Jednym $\mathrm{z}$ nich, najważniejszym, jest wymiar świadectwa. Ewangelizacja to nie teoretyzowanie na temat Ewangelii, to jej przepowiadanie poświadczone świadectwami życia własnego, a także nawróceń, uzdrowień duchowych i cielesnych swoich słuchaczy. Tylko takie „nauczanie religii" - per exempla - jest zdolne pogłębiać wiarę, uzdalniać do ofiary, służby, diakonii ${ }^{23}$.

W istocie Jezus nie opowiadał o królestwie Bożym; nie wykładał teoretycznie jego zasad. Jezus ogłaszał jego obecność wśród ludzi ${ }^{24}$. Ewangelizacja, ale również katechizacja, są w dużej mierze kwestią eklezjologiczną. Katecheza nie jest opowiadaniem, lecz zaproszeniem do królestwa Bożego.

\footnotetext{
${ }^{22}$ B. Ferrero, Czy jest tam ktoś?, przeł. T. Chudecki, Wydawnictwo Salezjańskie, Warszawa 1993 , s. 6.

${ }^{23}$ Por. EG, nr 28-30.

${ }^{24}$ Por. G. RYś, Moc wiary, s. 148.
} 


\section{KATECHETA - REEWANGELIZATOR XXI WIEKU}

Szczególnie w obecnym czasie istnieje potrzeba wystosowywania takich zaproszeń do współczesnych społeczeństw chrześcijańskich, które w dużej mierze cierpią na swoistą amnezję religijną. Jan Paweł II mówi wręcz o nowej ewangelizacji, o nowej katechizacji. W 1979 r. w Mogile powiedział, że „od krzyża w Nowej Hucie zaczęła się nowa ewangelizacja: ewangelizacja drugiego milenium” ${ }^{25}$. Musi być ona „dziełem wspólnym biskupów, kapłanów, zakonów i świeckich; dziełem rodziców i młodzieży”26. Dodajmy, musi być ona dziełem szczególnie katechetów-ewangelizatorów.

Od katechetów XXI wieku wymaga się prowadzenia wiernych - uczniów, słuchaczy - do królestwa Bożego tak oto, aby „wszyscy oni pracowali zgodnie, każdy na swój sposób, dla wspólnego dzieła"27, którym jest ewangelizacja - nowa ewangelizacja - wszystkich narodów nie tylko przez udzielanie chrztu, ale również przez nauczanie zachowywania przykazań Jezusa (por. Mt 28,19-20). Dotyczy to nie tylko społeczeństw zlaicyzowanych na zachodzie Europy, ale także i naszego, polskiego społeczeństwa ${ }^{28}$.

Współczesne społeczeństwa nominalnie chrześcijańskie wypracowały błędny pogląd, że katecheci, ewangelizatorzy, kapłani nie są im potrzebni, aby mogli dotrzeć do Chrystusa i Jego królestwa; że sami będą sobie „statkiem i sterem", że znają drogę. Nic bardziej błędnego. Adresatami nowej (drugiej) ewangelizacji są ci polscy katolicy, którzy kiedyś zostali ochrzczeni i byli osobami szczerze wierzącymi, ale nie zadbali (z różnych powodów) o rozwój, pogłębienie swojej wiary; stali się letnimi (Ap 3,15-16), a bywa, że i całkowicie zatracili więź z Chrystusem. Są członkami współczesnej Laodycei. Wiara nie odgrywa $\mathrm{w}$ ich życiu większej roli. $\mathrm{Z}$ pewnym zażenowaniem przyznają się do chrześcijaństwa; w ich życiowych postawach można jednak znaleźć wiele uprzedzeń, a nawet wrogości. Nie jest to wszelako pokolenie stracone. Raczej uśpione, które katecheta - reewangelizator winien poruszyć, obudzić; uświadomić, że u drzwi każdego człowieka stoi i kołacze Jezus Chrystus, wystarczy je otworzyć, by razem z Nim - z Chrystusem - wieczerzać przy wspólnym stole (por. Ap 3,20-21) ${ }^{29}$.

\footnotetext{
${ }^{25}$ JAN PAweŁ II, Homilia w czasie Mszy św. odprawionej przed opactwem oo. Cystersów w Mogile, Kraków-Nowa Huta, 9 czerwca 1979 r., w: TENŻE, Dzieła zebrane, t. 9, Kraków 2008, s. 151.

${ }^{26}$ Tamże.

${ }^{27} \mathrm{KK}, \mathrm{nr} 40$.

${ }^{28}$ Por. W. PAZERA, Koncepcja homilii $w$ dziele nowej ewangelizacji, [b.w.], Częstochowa 2002, s. 98-99. O problemach ewangelizacyjnych wobec postępującej sekularyzacji zob. EG, nr 64, 67.

${ }^{29}$ Por. W. PAzera, Koncepcja homilii w dziele nowej ewangelizacji, s. 101.
} 
W tych niełatwych dla Kościoła czasach, w których opinia publiczna poznaje skandale i nadużycia duchowieństwa - w tym także katechetów istnieje pilna potrzeba potwierdzenia niezastąpionej roli nauczycieli. Kościół nie może się bez nich obejść. Należy w tym celu ukazywać teologiczny i biblijny aspekt ewangelizacji oraz podkreślać ważność urzędu katechety nauczyciela, który na co dzień, nie od święta, spotyka się z wiernymi, począwszy od najmłodszych dzieci po młodzież i dorosłych. Sami katecheci również winni zyskać większą świadomość swojej tożsamości oraz powierzonej im przez Kościół misji ${ }^{30}$.

\section{JEZUS CHRYSTUS - WZÓR NAUCZYCIELA I KATECHETY}

Nikt nie przemawiał tak przekonująco jak Jezus Chrystus. Ten głos i nauczanie słychać do dzisiaj. Istotnym i pierwszorzędnym przedmiotem katechezy jest tajemnica Chrystusa (Ef 3,4). Katechizować to znaczy w pewien sposób doprowadzić kogoś do przebadania tej Tajemnicy: wydobycia jej niejako na światło dzienne, pokazania, na czym polega wykonanie tajemniczego planu, którego - używając słów św. Maksymiliana - jedynym bodźcem jest miłość Chrystusa (por. Ef 3,9.18-19) ${ }^{31}$. „Jest to więc odkrywanie w Osobie Chrystusa całego odwiecznego planu Bożego, który w Niej się wypełnił. Jest to dążenie do zrozumienia znaczenia czynów i słów Chrystusa oraz dokonanych przez Niego znaków, ponieważ zawierają one w sobie, a zarazem ukazują Jego Tajemnicę. W tym znaczeniu ostatecznym celem katechezy jest doprowadzić kogoś nie tylko do spotkania z Jezusem Chrystusem, ale do zjednoczenia, a nawet głębokiej z Nim zażyłości. Bo tylko On sam może prowadzić do miłości Ojca w Duchu Świętym i do uczestnictwa w życiu Trójcy Świętej” ${ }^{32}$.

Pierwszym Nauczycielem i Katechetą jest Jezus Chrystus z Nazaretu Droga, Prawda i Życie Kościoła. Tę jedyną Drogę powinni wskazywać, tę jedyną Prawdę przepowiadać, i to jedyne Życie zwiastować wiernym, słudzy Ewangelii - ewangelizatorzy, katecheci, nauczyciele wiary.

Każdy katecheta poprzez swe nauczanie i swój sposób życia winien przekazywać naukę i życie Chrystusa, aby można było o nim powiedzieć, że jego

\footnotetext{
${ }^{30}$ Por. P. J. Condes, Nowa ewangelizacja w rozumieniu Jana Pawła II, s. 58.

${ }^{31}$ Św. Maksymilian M. Kolbe, Pisma, cz. 2, Wydawnictwo Ojców Franciszkanów, Niepokalanów 2008, s. 215 [nr 879].

${ }^{32}$ Por. CT, nr 5; EG, nr 26.
} 
nauka nie jest jego, lecz jest nauką Jezusa Chrystusa (por. J 7,16); że to, co otrzymał od Pana, przekazuje swoim słuchaczom (por. 1 Kor 11,23). Taka postawa ewangelizacyjna wymaga od katechety stałego i pilnego studiowania Słowa Bożego, żarliwej modlitwy oraz pielęgnowania głębokiej zażyłości z Chrystusem ${ }^{33}$. Jedynym bowiem nauczycielem Ewangelii jest Jezus Chrystus. Słusznie zatem Jan Paweł II podkreśla w swej adhortacji katechetycznej, że „wielkość Chrystusa nauczającego oraz wewnętrzna spoistość i siła przekonująca Jego nauki płynie stąd, że Jego słowa, przypowieści i rozprawy nie dają się nigdy oddzielić od Jego życia i osoby”. Można stwierdzić, że całe życie Chrystusa było nieustannym nauczaniem. „Jego milczenie, cuda, modlitwa, miłość do ludzi, szczególnie troska o poniżonych i biednych, całkowite przyjęcie ofiary krzyżowej dla odkupienia ludzi, samo wreszcie zmartwychwstanie - są urzeczywistnieniem Jego słowa i wypełnieniem Objawienia" 34 .

Nauczyciel z Nazaretu i Golgoty „objawia ludziom Boga i, podobnie, człowiekowi człowieka; [...] zachowuje, uświęca i prowadzi; [...] mówi, żyje pobudza, porusza, naprawia, sądzi, przebacza, idzie z nami każdego dnia po drogach historii; który jako Nauczyciel przychodzi i przyjdzie w chwale" $" 35$.

\section{EWANGELIZATORZY I KATECHECI - NAŚLADOWCY NAUCZYCIELA Z NAZARETU}

W Jezusie Chrystusie katecheci mają wzór doskonały, niedościgły. Naśladowanie tego wzoru jest $\mathrm{w}$ istocie ich życiowym zadaniem. Zachęcają do tego również Dzieje Apostolskie. Cała Księga jest zapisem świadectw wierności pierwotnych katechetów Kościoła - pierwszych ewangelizatorów świata i wszystkich narodów, którzy ,trwali w nauce Apostołów i we wspólnocie w łamaniu chleba i w modlitwie" (Dz 2,42); nauczali w imię Jezusa nie Pawła, Apollosa czy Kefasa (1 Kor 1,12). To głoszenie miało swoją cenę, niosło ze sobą ofiarę, cierpienie (Dz 5,40). Pierwsi katecheci uznawali jednak zasadę, według której należy „bardziej słuchać Boga niż ludzi” (Dz 5,29).

W czasach po Zmartwychwstaniu i Wniebowstąpieniu Chrystusa pojawiają się wspaniali katecheci, heroldzi Słowa Bożego: św. Szczepan, który

\footnotetext{
${ }^{33}$ Tamże, $\mathrm{nr} 6$.

${ }^{34}$ Tamże, nr 9.

${ }^{35}$ Tamże.
} 
poniósł ofiarę życia za wierność dziełu ewangelizacji (Dz 7,54-60); św. Paweł, który w Rzymie ,głosił Królestwo Boże i nauczał o Panu Jezusie Chrystusie zupełnie swobodnie" (Dz 28,31), ale ostatecznie przypłacił swoją służbę śmiercią.

Doskonałych wzorów ewangelizatorów dostarczają nam również czasy poapostolskie - od Klemensa Rzymskiego ${ }^{36}$ po Orygenesa ${ }^{37}$, twórców wspaniałych homilii, nauk i traktatów. Następnie w epoce Ojców Kościoła poznajemy wspaniałych mówców i kaznodziejów, m.in. świętych: Cyryla Jerozolimskiego $^{38}$, Jana Chryzostoma ${ }^{39}$, Ambrożego ${ }^{40}$, Augustyna $^{41}$.

\section{TROSKA KOŚCIOŁA O KATECHIZACJĘ WIERNYCH}

Posługiwanie katechetyczne stanowiło i stanowi bardzo ważne zadanie. Sobór Trydencki przyznał w swych konstytucjach i dekretach pierwsze

\footnotetext{
${ }^{36}$ Klemens Rzymski († ok. 101) - w latach 91-101 biskup Rzymu, autor dwóch Listów do Koryntian. Por. B. Reicke, Clemens, [w:] Lexikon der Alten Welt, Bd. I: A-G, red. K. Bartels, L. Huber, Patmos Verlag GmbH \& Co. KG, Tübingen-Zürich 2001, kol. 645.

${ }^{37}$ Orygenes (185-254) - jeden z najbardziej płodnych komentatorów Pisma Świętego w epoce patrystycznej. Zajmował się egzegezą krytyczną oraz literalną; autor licznych, homilii i komentarzy do Ewangelii. Zob. Kompletna bibliografia przekładów dzieł Orygenesa na język polski z lat 1901-2003, oprac. W. Stawiszyński, w: H. Crouzel, Orygenes, przeł. J. Margański, Wydawnictwo Homini, Kraków 2004, s. 341-378.

${ }^{38}$ Cyryl Jerozolimski (315-386) - grecki biskup Jerozolimy, doktor Kościoła; zostawił po sobie dwie serie katechez (łącznie 24). CYryL Jerozolimski, Katechezy przedchrzcielne i mistagogiczne, tłum. W. Kania, seria: Biblioteka Ojców Kościoła 14, Wydawnictwo „M”, Kraków 2000, s. 394.

${ }^{39}$ Jan Chryzostom (350-407) - biskup Konstantynopola, pisarz chrześcijański, uznawany za największego kaznodzieję Kościoła Wschodu, doktor Kościoła. Autor 22 dzieł teologicznych, m.in. kanonu Boskiej Liturgii wg św. Jana Złotoustego; licznych kazań i homilii. Zob. M. STARoWIEYSKI, Bibliografia uzupetniajaca, w: J.N.D. Kelly, Złote Usta. Jan Chryzostom, przeł. K. Krakowczyk, Wydawnictwo: Homini, Bydgoszcz 2001, s. 322-327 [Bibliografia wydań Jana Chryzostoma i polskojęzycznych opracowań].

${ }^{40}$ Ambroży z Mediolanu (339-397) - arcybiskup Mediolanu, ojciec i doktor Kościoła; autor wielu dzieł, katechez, homilii, komentarzy egzegetycznych. Pełna lista polskich przekładów do 2004 r., zob. W. StawiszyŃski, Bibliografia patrystyczna 1901-2004, Wydawnictwo Homini, Kraków 2005, s. 43-59.

${ }^{41}$ Augustyn z Hippony (354-430) - biskup, filozof, teolog, organizator życia kościelnego, Ojciec i Doktor Kościoła (doctor gratiae), znakomity pisarz i kaznodzieja, autor wielu dzieł polemicznych, listów, pism i homilii objaśniających Pismo Święte, homilii-katechez na temat sakramentów, liturgii i świąt i wielu innych prac; szczególnie poczytnym do czasów obecnych są jego Wyznania. Wiele jego dzieł przetłumaczono na język polski, zob. W. STAWIszyŃski, Bibliografia patrystyczna 1901-2004, s. 81-145.
} 
miejsce katechezie, dając początek Katechizmowi rzymskiemu (1566) ${ }^{42}$. Dzieło zapoczątkowane przez Sobór Trydencki było kontynuowane przez następne lata. Kolejną edycję katechizmu wydał papież Pius V $(1908)^{43}$; ten katechizm jest nadal popularny ze względu na jego jasność i zwięzłość. Następny katechizm ukazał się po Soborze Watykańskim II, w 1966 roku, zredagowany przez biskupów holenderskich ${ }^{44}$. Stracił on ważność w 1992 r., kiedy został zredagowany nowy Katechizm Kościoła katolickiego ${ }^{45}$. Kościół przykładał i nadal przykłada wielką wagę do katechizacji swoich wiernych. Stąd też potrzebuje ona stałej odnowy, dostosowania do nowych wyzwań społecznych, cywilizacyjnych, kulturowych.

Katecheza jest prawem i obowiązkiem Kościoła - jego „świętym obowiązkiem" "46, tak jak „świętym obowiązkiem” jest ewangelizacja ${ }^{47}$. Ten obowiązek ten wynika z Chrystusowego powołania: „muszę głosić Dobrą Nowinę o królestwie Bożym, bo na to zostałem posłany" (Łk 4,43) ${ }^{48}$.

Katecheza stanowi etap ewangelizacji, jest jedną z form głoszenia Słowa Bożego w Kościele: jest działaniem eklezjalnym. W istocie to Kościół jest prawdziwym i rzeczywistym podmiotem katechezy ${ }^{49}$. Katecheza to pogłębiony przekaz orędzia zbawczego. „Katecheza jest wychowaniem w wierze dzieci, młodzieży i dorosłych, a obejmuje przede wszystkim nauczanie doktryny chrześcijańskiej, przekazywane na ogół w sposób systematyczny

42 Zob. G. J. Bellinger, Bibliographie des Catechismus Romanus. Ex Decreto Concilii Tridentini ad Parochos 1566-1978, Verlag Valentin Koerner, Baden-Baden 1983; por._W. ОкоŃ, Nowy stownik pedagogiczny, Wydawnictwo Akademickie Żak, Warszawa 2001, s. 162.

${ }^{43}$ Pıo X, Catechismo della dottrina Christiana, Fratelli Lanzani Tipografi, Milano 1908.

${ }^{44}$ Katechizm holenderski od 1967 r. był tłumaczony na wiele języków i został sprzedany w milionach egzemplarzy. W wielu kręgach uznawany za kontrowersyjny, m.in. bp Robert F. Joyce (USA) wycofał po pewnym czasie swoje imprimatur. Według redaktora „Frondy”: „Wśród herezji zawartych w holenderskim katechizmie znalazły się m.in. takie błędy, jak: brak stwierdzenia, że dusze ludzkie zostały bezpośrednio stworzone przez Boga; nieobecność aniołów; twierdzenie, że grzech pierworodny jest przekazywany nie dziedzicznie, lecz epidemicznie, tzn. jest nabyty przez życie w ludzkiej społeczności; brak potwierdzenia Niepokalanego Poczęcia Maryi; brak stwierdzenia, że Chrystus umarł za grzechy ludzi; brak potwierdzenia rzeczywistej obecności Chrystusa w Eucharystii; podważenie doktrynalnej nieomylności Kościoła itd.” G. GóRnY, Holenderski prometeizm, „Przewodnik Katolicki” 2003, nr 27, s. 32-33.

${ }^{45}$ Katechizm Kościoła katolickiego, Pallottinum, Poznań 1994.

${ }^{46}$ Por. CT, nr 14, 16.

${ }^{47}$ Por. EG, nr 33.

${ }^{48}$ Por. EN, nr 12.

${ }^{49}$ Zob. DK, nr 18. Szeroko na temat katechezy i jej definicji zob. KongregaCJA do SpRAw DuchowiEŃstwa, Ogólna instrukcja katechetyczna (1971) [dalej: DOK], w: Katecheza po Soborze Watykańskim II w świetle dokumentów Kościoła, red. W. Kubik, t. 1, Akademia Teologii Katolickiej, Warszawa 1985. 
i całościowy, dla wprowadzenia wierzących w pełnię życia chrześcijańskiego" ${ }^{\circ 0}$.

Nadrzędnym celem katechezy jest więc komunia z Jezusem Chrystusem, osiągana „przez realizację celów cząstkowych i pośrednich, związanych z sytuacją, w jakiej żyją i wzrastają konkretni adresaci katechezy"51. Stąd wynika pilna potrzeba korygowania programów katechetycznych, przystosowując je do aktualnej sytuacji duszpasterskiej. Szczegółowymi zadaniami katechezy są: rozwijanie poznania wiary, wychowanie liturgiczne, formacja moralna, nauczanie modlitwy, wychowanie do życia wspólnotowego oraz wprowadzenie do misji ${ }^{52}$.

Głównym źródłem katechezy jest Pismo Święte oraz Tradycja, w których zawarte jest żywe Słowo Boże. To Słowo można znaleźć w liturgii, refleksji teologicznej Kościoła oraz w autentycznych wartościach religijnych i moralnych w różnych kulturach. Miejscami Słowa Bożego są także: zmysł wiary Ludu Bożego oraz życie Kościoła zapisane w jego historii oraz w świadectwach świętych ${ }^{53}$. Filarami zaś katechezy są: trzy etapy opowiadania historii zbawienia, tj. w Starym Testamencie, w życiu Jezusa Chrystusa oraz w historii Kościoła; oraz cztery filary wykładu, obejmujące: Symbol Wiary, sakramenty, przykazania i Modlitwę Pańską ${ }^{54}$.

Głównym kryterium przedstawiania orędzia ewangelicznego w katechezie jest istotna łączność nauczania katechetycznego z Ewangelią. Orędzie zbawienia przekazywane $\mathrm{w}$ katechezie powinno być skoncentrowane na osobie Jezusa Chrystusa, na głoszeniu królestwa Bożego, mieć charakter eklezjalny, przy uwzględnieniu zasad inkulturacji, ale tak, aby to orędzie było przedstawiane w całej integralności i czystości wiary ${ }^{55}$.

\section{GRZECHY KATECHETY}

W obecnej rzeczywistości społecznej i cywilizacyjnej mamy do czynienia z kryzysem słowa. Kryzys ulokował się zatem tam, gdzie człowiek dotąd znajdował nadzieję. Nie należy jednak zapominać, że deprecjacja słowa nastąpiła wiele lat temu, jeszcze w epoce elżbietańskiej (XVI). Nie kto inny

\footnotetext{
${ }^{50} \mathrm{CT}$, nr 18 .

${ }^{51} \mathrm{DK}, \mathrm{nr} 22$.

${ }^{52}$ DOK, nr 86-87.

${ }^{53}$ Por. DK, nr 32.

${ }^{54}$ Tamże, nr 33; DOK, nr 130.

${ }^{55}$ Por. DOK, nr 97; DK, nr 36.
} 
jak W. Szekspir zawarł w Hamlecie (Akt II, scena 2) znaną wszystkim wypowiedź: „Słowa, słowa, słowa...”

Zewsząd otaczają nas słowa. Potop słów. Woda, woda, woda. Ilość tej „wody” nie przechodzi w jakość. Nastąpiła wielka dewaluacja słowa. Słowa już nic nie znaczą. Nie mają mocy stwórczej. Przeciwnie, słowa niszczą ziemię i człowieka. W tym zalewie słów znajduje się również Słowo Boże. Co należy uczynić, by i Ono „nie popłynęło” z prądem tego świata?

Niejednokrotnie z katechezy Słowa wyłania się zwykły komunał i beznadzieja. Nauka religii nie przynosi z sobą pogłębienia wiary ani nawet pogłębienia wiedzy religijnej, poznania treści zawartych w Piśmie Świętym. Słuchacze, już ci najmłodsi, z powodzeniem potrafią obchodzić się z komputerem, smartfonem, surfując po Internecie, nie potrafią zaś „surfować” po Biblii. Biblia to biała plama, stąd katecheta nie może skutecznie ewangelizować, gdyż nie może powoływać się na Słowo w niej zawarte - Słowo nieznane dla słuchaczy. Kiedy czyta się kazania Ojców Kościoła, zadziwia wielość porównań, alegorii, odniesień do Starego Testamentu. Widać stąd, że tamten starożytny słuchacz znał Pismo Święte, choć często nie umiał czytać. Wiedzę biblijną przekazywali mu kaznodzieje, katecheci. Robili to na tyle skutecznie, że zapamiętał.

Dzisiaj sytuacja jest zgoła odmienna. Słuchacze nie znają Ewangelii, a Stary Testament jest terra incognita. Dotyczy to nie tylko słuchaczy, ale coraz częściej samych katechetów - pożal się Boże ewangelizatorów...

Do czego odnoszą się współcześni katecheci w swoim ewangelizowaniu? Odnoszą się do tego, na czym znają się najlepiej. Na czym znamy się najlepiej? Na polityce! Stąd liczne odniesienia polityczne - zamiast żywego Słowa Ewangelii. A Słowo przecież pochodzi od Boga. Ma moc kreacji, tworzenia świata na nowo. Katecheta winien się włączyć w dzieło kreacji dzieło Słowa. Bóg rzekł i stało się. Rzekł katecheta - i nic się nie stało... Słuchacze, uczniowie odeszli. Nie dlatego, że mowa była rudna $(\mathrm{J} 6,60)$. Dlatego, że była nudna, nijaka, bezwartościowa. Bez mocy tworzenia czegoś z niczego. Bez mocy odmieniania rzeczywistości i człowieka. Bez mocy Ducha. Nie wynosi człowieka do duchowych wymiarów jego człowieczeństwa aż po same Niebo ${ }^{56}$. A przecież każdy człowiek, a katecheta-ewangelizator $\mathrm{w}$ sposób szczególny został powołany do tworzenia ex nihilo nowego świata: królestwa Bożego na ziemi.

Jaka zatem winna być katecheza i katecheta XXI wieku? A jaka jest?

\footnotetext{
${ }^{56}$ Por. A. OsŁawSKA, Kaznodziejstwo chrześcijańskie na horyzoncie XXI wieku, s. 285.
} 
Wszyscy jej odbiorcy odczuwają co najmniej niedosyt, nudę, uczucie amnezji. Nikt nie pamięta kazania, a co dopiero przesłania z lekcji religii. Owszem, można odnaleźć w tym stogu siana (słomy?) igłę ze złotym uszkiem, ale przecież nie chodzi o ekstraordynaryjne przypadki, lecz o codzienność katechezy. Ta zaś jest szara i nie napawa optymizmem ${ }^{57}$.

Najczęstsze grzechy współczesnego katechety (katechezy) to letniość i lenistwo, brak pasji ze strony reewangelizatora czy katechety ${ }^{58}$. To brak jasnego wyłożenia treści i komentarza, brak umiejętności odnajdywania współczesnych odniesień do historycznych sensów Biblii. To brak logiki przekazu, banalny - czasami niechlujny - język. I przede wszystkim beznadziejność przekazu - brak nadziei, która przecież winna być jego atutem katechety, pochodzącej z jego wiary ${ }^{59}$.

Tymczasem katecheci ulęgają ogólnemu trendowi wypowiadania się. Przygnieceni nadmiarem pseudouczonych, parafilozoficznych frazesów, głoszą Dobrą Nowinę w tak nieludzki, zimny sposób, że - jak słusznie zauważa Anna Osławska ${ }^{60}-$,już więcej ciepła w reklamach towarów pierwszej potrzeby" niż w przekazie Ewangelii ${ }^{61}$. A Ewangelia jest przecież Dobrą Nowiną, nowiną radosną, którą ewangelizatorzy i katecheci winni odnawiać i dzielić jej radość z innymi ${ }^{62}$.

\section{PRAKTYCZNE WSKAZANIA, PERSPEKTYWY I PROPOZYCJE PASTORALNE KATECHEZY}

Katecheza ewangelizująca winna nieść przesłanie związane z charakterem Dobrej Nowiny. Trudno jednak zgodzić się do końca ze zdaniem Wojciecha Pazery, który przestrzega przed wprowadzaniem w chrześcijańskie przepowiadanie stylu katastroficznego, wypływającego jakoby z wizji Apokalipsy, która - zdaniem autora - byłaby ważniejsza od radosnej prawdy

\footnotetext{
${ }^{57}$ Tamże, s. 286-287.

${ }^{58}$ Por. EG, $\mathrm{nr} 81-82$.

${ }^{59}$ Tamże, s. 288.

${ }^{60}$ Anna Osławska (1957-2014) - absolwentka teatrologii UJ, reżyserii dramatu PWST w Krakowie. Autorka tekstów dla teatru, radia i TV, współtwórczyni i dyrektor artystyczny Theatrum Mundi. Reżyser teatralny, nauczyciel akademicki (kształcenie artystyczne, kultura języka, historia teatru). Anna Ostawska, http://www.retoryka.polonistyka.uj.edu.pl/mgr-anna-oslawska (dostęp: 29.02.2020).

${ }^{61}$ Por. A. OsŁawsKa, Kaznodziejstwo chrześcijańskie na horyzoncie XXI wieku, s. 291; zob.

${ }^{62} \mathrm{EG}, \mathrm{nr} 87$.
} EG, $\mathrm{nr} 83$. 
Zmartwychwstania ${ }^{63}$. Wydaje się, że nie należy przeciwstawiać Apokalipsy Ewangelii, gdyż właśnie Apokalipsa jest wypełnieniem Dobrej Nowiny, opisem skutków paruzji, której pierwocinami było Zmartwychwstanie. Należy zatem ciągle uzmysłowiać słuchaczom (i sobie), że perspektywa Apokalipsy jest częścią Radosnej Nowiny (zob. Ap 21,1-21; 22,12-14.16-21). I chociaż, o czym nie wolno zapominać, na Golgotę dotarł tylko jeden z Apostołów, a sam Jezus przegrał w referendum z Barabaszem, to jednak chrześcijaństwo nie uległo depresji, bo zawsze znajdowali się ludzie, „którzy potrafili odczytywać nową treść w przesłaniu Wieczernika i nieść prawdę Ewangelii w głęboko zmienione realia" ${ }^{64}$. Potrafili to uczynić uczniowie idący do Emaus oraz całe szeregi wyznawców Chrystusa w okresie okrutnych prześladowań w pierwszych trzech wiekach oraz w nie mniej groźnym saeculum obscurum oraz czasach wyzwań, które niosły z sobą Średniowiecze, Renesans, Reformacja, Oświecenie (wiek rozumu i krytyki Kościoła), aż po czasy współczesne, w których narodziły się potężne totalitaryzmy oraz zgubne ideologie, wkraczające brutalnie w życie jednostek i społeczeństw (LGBT+, gender).

Owa odwieczna umiejętność Kościoła, nie tylko przetrwania, ale i wzrostu poprzez różne formy przepowiadania, w tym przez ewangelizację i katechezę, niesie nadzieję, ale jest również kolejnym, nowym wyzwaniem do poszukiwania takich metod ewangelizacyjnych, które zdominowałyby światowe rozczarowania i frustracje. Ponad nie wyrasta bowiem optymizm Ewangelii. Stąd też katecheta-ewangelizator winien być widzialnym znakiem owego optymizmu, a nie stojącym w bramie dantejskiego Piekła ponurakiem z wypisanym w oczach przesłaniem z Boskiej komedii: „Lasciate ogni speranza voi ch'entrate" 65 .

Nie wolno bowiem zapominać, że podstawowym warunkiem skuteczności katechizacji prowadzonej w ramach ewangelizacji i reewangelizacji jest nie tylko świadectwo słowa, ale również bardzo ważny jest jego związek ze świadectwem życia katechety. Katecheza winna oddziaływać na kulturę społeczną, narodową oraz kształtować mentalność człowieka. Nie będzie jednak w stanie tego dokonać, jeśli katecheta nie utożsami się z chrześcijańską maksymą, według której myśl chrześcijańska znajduje zawsze swoją mani-

\footnotetext{
${ }^{63}$ Por. W. PAzera, Koncepcja homilii w dziele nowej ewangelizacji, s. 318.

${ }^{64}$ J. ŻYCIŃSKI, Wizja nowej ewangelizacji przestaniu II Specjalnego Synodu Biskupów Europy a obecne problemy duszpasterskie Kościoła $w$ Polsce, w: Komisja DusZPasterstwa Ogólnego KEP, Program duszpasterski na rok 2000/2001, Księgarnia Św. Jacka, Katowice 2000, s. 39; por. W. PAzera, Koncepcja homilii $w$ dziele nowej ewangelizacji, s. 318-319.

${ }^{65}$ Por. A. OsŁawsKa, Kaznodziejstwo chrześcijańskie na horyzoncie XXI wieku, s. 284.
} 
festację w słowie, a słowo - w czynie. Nie może być rozdźwięku między myślą, słowem i życiem ${ }^{66}$.

Katecheta nie może być ewangelizatorem jedynie w szkole podczas lekcji religii. Obowiązek ewangelizacji wychodzi daleko poza mury szkoły i kościoła - „na cały świat” (Mk 16,15). Ewangelizator nie może się wstydzić Ewangelii. Nie może o niej milczeć w przestrzeni świeckiej i często prześmiewczej. Musi na co dzień dowodzić prawdy głoszonego przez siebie Słowa - swoim życiem. Wiara bez uczynków jest martwa (Jk 2,14-18). Także nauczanie wiary bez uczynków jest zajęciem bezprzedmiotowym.

Cała misja ewangelizacyjna katechety nie może być oderwana od rzeczywistości, od realiów otaczających słuchaczy, lecz winna być dostosowana do ich mentalności; winna „odpowiadać ludziom na ich odwieczne pytania dotyczące sensu życia obecnego i przyszłego oraz wzajemnego ich stosunku do siebie" ${ }^{67}$. Bezwzględnym warunkiem takiego przepowiadania jest właściwe rozpoznanie rzeczywistości oraz odczytanie ich w świetle Ewangelii bez uszczerbku dla Prawdy.

Ewangelizacja w swojej formie nie może być nazbyt polemiczna czy wręcz agresywna ${ }^{68}$. Jezus z Nazaretu był w istocie łagodnym Nauczycielem. $Z$ łagodnością zwracał się tak do pojedynczych ludzi (J 3,3), jak i do tłumów (Mt 5,1-7,28; Łk 6,17-49), użalając się nad potrzebującymi; czasami wystarczyło jedno Jego słowo: „Nie płacz” (Łk 7,13). Dlatego wszyscy słuchacze odchodzili pełni wdzięczności, podziwu i ufności.

Współczesny ewangelizator i katecheta dysponują wieloma narzędziami w pracy misyjnej. Najpotężniejszymi są media społecznościowe, a szerzej Internet. Wszyscy się dzisiaj komunikują za pomocą smartfonów. Katecheta też człowiek - ma swojego smartfona. Ile w nim (w smartfonie) można znaleźć treści religijnych, przekazu ewangelicznego, wiadomości katechetycznych kierowanych do licznych znajomych na Facebooku, na Tweeterze i innych platformach cyfrowych? Czym się dzielisz ze swoimi znajomymi? Co przesyłasz dalej?

Pokaż mi swój smartfon, a powiem ci, jakim jesteś ewangelizatorem. Jakim jesteś katechetą. Nie tylko bowiem z ambony czy szkolnej „katedry”, ale również za pomocą współczesnych mass mediów należy dzielić się Dobrą Nowiną. Mediami już w okresie międzywojennym doskonale posłu-

\footnotetext{
${ }^{66}$ Por. W. PAzera, Koncepcja homilii w dziele nowej ewangelizacji, s. 325.

${ }^{67}$ Por. Sobór WATYKŃSKi II, Konstytucja duszpasterska o Kościele w świecie współczesnym Gaudium et spes, w: Sobór Watykański II. Konstytucje, Dekrety, Deklaracje, tekst polski, nowe tłumaczenie, Poznań 2012, nr 4.

${ }^{68}$ Por. EG, nr 44.
} 
giwał się św. Maksymilian, kiedy prasa była najpotężniejszym i najbardziej skutecznym narzędziem formowania ludzkich umysłów i dusz. Obecnie prasa nie ma już takiego znaczenia. Wielość tytułów katolickich periodyków nie jest w stanie przebić się przez wszędobylskie media społecznościowe czy portale internetowe. Należy je zaprząc do misji ewangelizacyjnej i katechizacyjnej. Informacja z sieci dociera dziś praktycznie do każdego człowieka. Dlaczego tą informacją - i to informacją zmasowaną! - nie miałaby być Dobra Nowina? Wydaje się, że prasa tradycyjna (papierowa) obecnie jest już passé. Należy zatem korzystać z narzędzi nowoczesnych, najnowszych, najbardziej zaawansowanych technologicznie. Tak czynił św. Maksymilian, który wyprzedzał swoją epokę. Stworzył potężny ośrodek wydawniczy, posługiwał się dalekopisem, wykorzystywał radio; interesował się telewizją, do kolportażu planował wykorzystać lotnictwo. Osiągnięcia techniki i media uważał za dobre same w sobie. Ale nie tylko przez media o. Kolbe ewangelizował swoje otoczenie. Stosował również ewangelizację bezpośrednią; wychodził na ulice, docierał do zakładów pracy i środków komunikacji publicznej, rozdając swoje pisma. Ewangelizacja i katechizacja powinny posługiwać się językiem jasnym, prostym, komunikatywnym i odważnym nieskażonym poprawnością polityczną; nazywać rzeczy po imieniu ${ }^{69}$.

\section{ZAKOŃCZENIE}

Problematyka współczesnej ewangelizacji (reewangelizacji, nowej ewangelizacji, drugiej ewangelizacji) oraz katechizacji jest tematem istotnym dla życia i historii Kościoła. Bez wypracowania nowych metod i nowego podejścia do współczesnego człowieka trudno jest mówić o skuteczności reewangelizacji oraz katechizacji. Wszystko się zmienia: zmienia się świat, zmienia się mentalność człowieka; niezmienne jest jedynie zbawcze orędzie Chrystusa - apostolski kerygmat. Owa niezmienność stanowi o jego wartości. Stąd też tak ważne jest, by katecheta XXI wieku w zmieniającym się świecie głosił niezmienną Prawdę o zbawieniu. Winien przy tym używać metod i narzędzi stosownych do wymogów rzeczywistości, w której się znajduje. Nie mogą być one anachroniczne. Stare bukłaki należy zastąpić nowymi.

Nowa ewangelizacja i nowe podejście katechetyczne wymaga zatem nowych katechetów - ludzi nie wyobcowanych, nie wyalienowanych, lecz pozostających we wspólnocie z Kościołem. W adhortacji Evangelii gaudium

\footnotetext{
${ }^{69}$ Por. T.A. JAnusz, Media pasją św. Maksymiliana, „Niedziela” 2001, nr 46, s. 22.
} 
papież Franciszek apeluje: „Nie dajmy się okraść ze wspólnoty!”70. Ewangelizatorzy, katecheci, wszyscy uczniowie Pana zostali powołani nie tylko do życia we wspólnocie, ale również do wspólnotowego głoszenia Ewangelii, czyli do dawania „świadectwa o przynależności ewangelizującej zawsze w nowy sposób" "71. To właśnie świadectwo definiuje ewangelizatora i katechetę XXI wieku.

Odpowiedź na postawione na początku pytanie może być tylko jedna: katecheta to nauczyciel na miarę Nauczyciela z Nazaretu.

\section{BIBLIOGRAFIA}

Bellinger G.J., Bibliographie des Catechismus Romanus. Ex Decreto Concilii Tridentini ad Parochos 1566-1978, Verlag Valentin Koerner, Baden-Baden 1983.

Cordes P. J., Nowa ewangelizacja w rozumieniu Jana Pawła II, „L’Osservatore Romano” 4 (2012), s. 57-60.

Cyryl Jerozolimski,_Katechezy przedchrzcielne i mistagogiczne, thum. W. Kania, Wydawnictwo M, Kraków 2000. Seria: Biblioteka Ojców Kościoła 14.

FrANCISZEK, Adhortacja Apostolska Evangelii gaudium, Rzym 2013, https://opoka. org.pl/biblioteka/ W/WP/franciszek_i/adhortacje/evangelii_24112013.html (dostęp: 02.04.2020).

GŁowa W., Liturgia miejscem i źródłem przepowiadania, Wydawnictwo Archidiecezji Przemyskiej, Przemyśl 1999.

GóRnY G., Holenderski prometeizm, „Przewodnik Katolicki” 2003, nr 27, s. 32-33.

JAN PAWE€ II, Adhortacja Apostolska o katechizacji w naszych czasach Catechesi tradendae, Rzym 1979, w: https://opoka.org.pl/biblioteka/W/WP/ jan_pawel_ii/adhortacje/catechesi.html (dostęp: 02.04.2020).

JAN PAWEŁ II, Encyklika Redemptoris Mater, https://opoka.org.pl/biblioteka/W/WP/jan_pawel_ii/ encykliki/r_mater_1.html [dostęp: 01.04.2020].

JAN PAWEe II, Homilia w czasie Mszy św. odprawionej przed opactwem oo. Cystersów w Mogile, Kraków-Nowa Huta, 9 czerwca 1979 r., w: TeNŻe, Dzieła zebrane, t. 9, Wydawnictwo „M”, Kraków 2008.

JAN PAWEe II, Posynodalna Adhortacja Apostolska Christifideles laici, https://opoka.org.pl/ biblioteka/W/WP/jan_pawel_ii/adhortacje/christifideles.html (dostęp: 01.04.2020).

JANusz T. A., Media pasją św. Maksymiliana, „Niedziela” 2001, nr 46, s. 22.

Katechizm Kościoła katolickiego, Pallottinum, Poznań 1994.

Kompletna bibliografia przekładów dzieł Orygenesa na język polski z lat 1901-2003, oprac. W. Stawiszyński, w: H. Crouzel, Orygenes, przeł. J. Margański, Wydawnictwo Homini, Kraków 2004, s. 341-378.

\footnotetext{
${ }^{70} \mathrm{EG}, \mathrm{nr} 92$.

${ }^{71}$ Tamże
} 
Kongregacja do Spraw Duchowieństwa, Ogólna instrukcja katechetyczna, w: Katecheza po Soborze Watykańskim II w świetle dokumentów Kościoła, red. W. Kubik, t. 1, Akademia Teologii Katolickiej, Warszawa 1985.

Murawski R., Katecheza, w: Katolicyzm A-Z, red. Z. Pawlak, Wydawnictwo: Księgarnia Św. Wojciecha, Poznań 1982, s. 198-200.

OкоŃ W., Nowy słownik pedagogiczny, Wydawnictwo Akademickie Żak, Warszawa 2001.

OsŁawska A., Kaznodziejstwo chrześcijańskie na horyzoncie XXI wieku, w: W nurcie odnowy przepowiadania homilijnego, red. nauk. I. Kosmana, L. Pintal, Wydawnictwo Ojców Franciszkanów, Niepokalanów 2011, s. 283-293.

PAwEe VI, Adhortacja Apostolska o ewangelizacji w świecie współczesnym Evangelii nuntiandi, Rzym 1975, thum polskie aprobowane przez KEP: „Miesięcznik Kościelny Archidiecezji Poznańskiej” 1975. https://opoka.org.pl/biblioteka/W/WP/pawel_vi/adhortacje/evangelii_ nuntiandi.html (dostęp: 02.04.2020).

PaZera W., Koncepcja homilii w dziele nowej ewangelizacji, [b.w.], Częstochowa 2002.

Pio X, Catechismo della Dottrina Christiana, Fratelli Lanzani Tipografi, Milano 1908.

Reicke B., Clemens, w: Lexikon der Alten Welt, Bd. I: A-G, red. K. Bartels, L. Huber, Patmos Verlag GmbH \& Co. KG, Tübingen-Zürich 2001, kol. 645.

RYŚ G., Moc wiary, Wydawnictwo WAM, Kraków 2017.

Sikora A., Chrzest jako źródło apostolstwa świeckich, „Teologia i Moralność” 10 (2015), nr 1, s. 81-91.

SŁAwiŃSKi H., Rola homilii w liturgii Kościoła, „Studia Włocławskie” 4(2001), s. 289-303.

Sobór WATYKŃski II, Konstytucja dogmatyczna o Kościele Lumen gentium, w: Sobór Watykański II. Konstytucje, Dekrety, Deklaracje, tekst polski, nowe tłumaczenie, Poznań 2012.

SoBór WATYKŃSKi II, Konstytucja duszpasterska o Kościele w świecie współczesnym Gaudium et Spes, w: Sobór Watykański II. Konstytucje, Dekrety, Deklaracje, tekst polski, nowe thumaczenie, Poznań 2012.

Starowieyski M., Bibliografia uzupełniająca, w: J.N.D. Kelly, Złote Usta. Jan Chryzostom, przeł. K. Krakowczyk, Wydawnictwo: Homini, Bydgoszcz 2001, s. 322-327 [Bibliografia wydań Jana Chryzostoma i polskojęzycznych opracowań].

StawiszyŃSKi W., Bibliografia patrystyczna 1901-2004, Wydawnictwo Homini, Kraków 2005.

Św. Maksymilian M. Kolbe, Pisma, cz. 2, Wydawnictwo Ojców Franciszkanów, Niepokalanów 2008, [nr 879].

Wykaz publikacji Księdza Profesora Romana Murawskiego SDB, „Seminare” 2001, nr 17, s. 23-31.

ŻYCIŃSKI J., Wizja nowej ewangelizacji przesłaniu II Specjalnego Synodu Biskupów Europy a obecne problemy duszpasterskie Kościoła w Polsce, w: Komisja DuszPasterstwa OGÓlnego KEP, Program duszpasterski na rok 2000/2001, Księgarnia Św. Jacka, Katowice 2000 .

\section{KATECHETA XXI WIEKU - NAUCZYCIEL RELIGII CZY EWANGELIZATOR?}

$$
\text { Streszczenie }
$$

Na podstawie dokumentów Kościoła oraz opracowań teologicznych autor ukazuje wyzwania dla katechety-ewangelizatora XXI wieku w kontekście zmieniającego się świata oraz nowej 
(drugiej) jego ewangelizacji. Współcześni chrześcijanie - ludzie ochrzczeni - daleko odeszli od Chrystusa. Stąd potrzeba reewangelizacji i rekatechizacji nominalnie wierzących społeczeństw. Celem tak rozumianej katechezy ewangelizującej jest doprowadzenie tego świata ponownie do Chrystusa, nawiązanie z Nim więzi i pogłębienie wzajemnych relacji: Bóg - człowiek.

W artykule przeanalizowano braki i błędy współczesnego katechety. Podano również propozycje i wskazania pastoralne oraz ukazano perspektywy dla nowych ewangelizatorów. Kościół stoi przed wielką misją. Jest nią nie tylko poszerzanie grona uczniów Pana, ale również odzyskiwanie straconych, którzy „się wycofali i już z Nim nie chodzą” (por. J 6,66). Ewangelizator w nieustannie laicyzującej się i sekularyzującej rzeczywistości może przeciwstawiać żywe Słowo Boga oraz własne żywe świadectwo. Obecnie ma do dyspozycji wiele narzędzi, by dotrzeć do odbiorców - dawnych uczniów, którzy zniechęcili się do Kościoła z racji bądź to jego „trudnej mowy" (J 6,60) bądź też skandali i nadużyć duchowieństwa. Kościół jest zdeterminowany, by wciąż potwierdzać niezastąpioną rolę nauczycieli w jego misji. Jest to również zadanie dla samych katechetów, którzy utożsamiając się z Nauczycielem z Nazaretu, winni być świadomi misji, którą powierzył im Kościół.

Słowa kluczowe: ewangelizacja; katechizacja; katecheta; nauczyciel; ewangelizator. 